
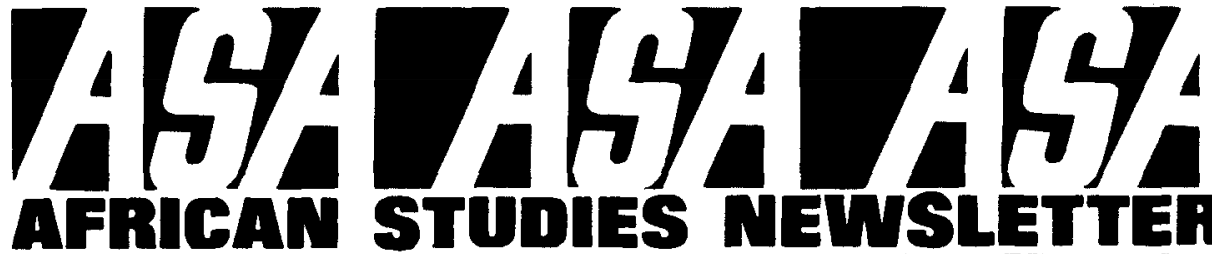

\title{
CONTENTS
}

Minutes

Archives-Libraries Committee Meeting . . . . . . . . . 2

Current Issues Committee Meeting . . . . . . . . . . . . 3

ASA Financial Statement . . . . . . . . . . . . . . 4

Letter ... . . . . . . . . . . . . . . . . . . 4

Additional Papers Presented at the 20th Annual Meeting

of the African Studies Association . . . . . . . . . . . 6

Special Announcements . . . . . . . . . . . . . 66

SPECIAL INSERT

PROGRAM/1978 ANNUAL MEETING

Meetings-Past \& Future . . . . . . . . . . . . 7

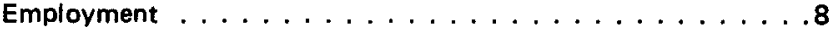

Grants \& Awards .................... 10

\section{AFRICAN STUDIES ASSOCIATION ANNUAL MEETING}

The 1979 ASA annual meeting will be held in Los Angeles at the Los Angeles Hilton Hotel, October 29-November 3, 1979. The Program Director is Bennetta Jules-Rosette, Department of Sociology, University of Californie, La Jolla, California 92030. The central theme for the meeting will be "Changing Aspects of Communication in Africa," although papers and panel suggestions on other themes are welcome. If you wish to participate in the meeting, please contact Professor Jules-Rosette. Final date for submission of paper proposals will be April 15, 1979. 